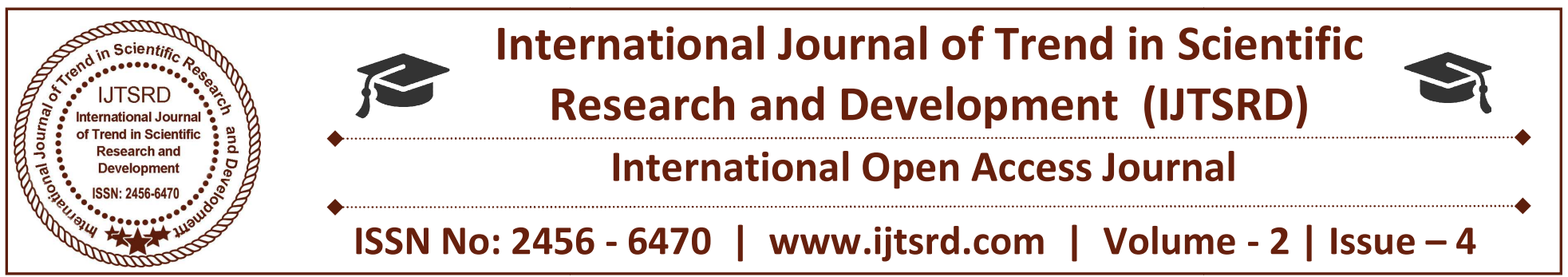

\title{
Comparative Analysis of Ground Water \& Surface Water of Kolhapur based on various Physico-Chemical Parameters
}

\author{
A. A. Adsule ${ }^{1}$, Dr. G. S. Kulkarni ${ }^{2}$ \\ ${ }^{1}$ Student, ${ }^{2}$ Professor \\ Environmental Science \& Technology, Department of Technology, \\ Shivaji University, Kolhapur, Maharashtra, India
}

\section{ABSTRACT}

Kolhapur city is one of the major cities in Maharashtra and well source of water bodies available in the western region of Maharashtra. But still facing the water scarcity in summer days due to the polluted water is unfit to use. Kolhapur district and city have major problems with water quality. Some of the parts of district blessed with River or lakes but due to human activities pollute the surface water sources. Groundwater table lowering day by day pass or contaminated due to industrial activities. So basically, it is not fit for drinking and for also irrigation purpose. This review paper is to analyze the groundwater and also surface water physicochemical parameter analysis and potential of calculating parameters and remedies the effect of pollution activities.

Keywords: Ground water, Surface water, Physicochemical, Water Quality, Kolhapur.

\section{INTRODUCTION}

Water is one of the most valuable and delicate compounds of the ecosystem. All living things on the earth need water for their survival and growth, and on earth having about $70 \%$ of water which only $3 \%$ is fresh water, reaming water is in the saline state. Water is categorised into two groups which is surface water and groundwater. In general Groundwater is located underground in large aquifers and must be pumped out of the ground after drilling a deep well. Surface water is available in lakes, rivers and streams and is use to the public water supply by an intake. Due to the minerals drained while water escaping through the rocks, so that's how groundwater is typically get mineralise and due to high mineral content such water considered to be "hard" water. Surface water it is water found in a river, lake or other surface cavity. This water is usually not having very large amount in mineral content, and it's called "soft water". Surface water is exposed to the atmosphere and interferes with human activities and also affected by many different contaminants, such as animal wastes, pesticides, insecticides, industrial wastes and many other organic materials. Surface water found in mountain streams and valleys can be contaminated by wild animal waste, dead animals upstream or other decay horticulture compound. Groundwater is described as water that contained by a subsurface layer of soil or rock. Groundwater stored into the layer of soils, between pervious and impervious strata. While passing through rocks they absorb some minerals or get contaminated by various elements from rock strata, that how it becomes "Hard Water". However, groundwater contains less contamination as compare to surface water due to soil and rock strata remove excessive minerals and other constituents.

\section{Literature Review:}

Patil Shilpa G. et. al. (2011) conducted Shivaji university campus lakes survey of physical and chemical parameters analysis for drinking and other useful purposes. They tested water collected one liter for 6 month period and come to conclusion on the reading analysis that water is polluted through various activities by the local residential public. The deference's in physicochemical parameters such as 
Temperature, Transparency, Turbidity, Total Dissolved Solids, $\mathrm{pH}$, Dissolved Oxygen, Free Carbon dioxide, Total Hardness, Chlorides, Alkalinity, Phosphate, Nitrates, and MPN were analyzed form a period of September 2010 to February 2011. The Rajaram lake water testing results found such as Temperature $14.33-25^{\circ} \mathrm{C}, \mathrm{pH}$ varies $7.7-8.3$, Turbidity $6.6-10.1$ NTU, Hardness $89-$ $206 \mathrm{mg} / \mathrm{l}$, Alkalinity $52-161 \mathrm{mg} / \mathrm{l}$, Acidity $15.6-$ $32.6 \mathrm{mg} / 1$, D.O. 3.2 - $4.7 \mathrm{mg} / \mathrm{l}$, B.O.D. $6.7-33.71$ $\mathrm{mg} / \mathrm{l}$, C.O.D. 24.2 - $152.3 \mathrm{mg} / \mathrm{l}$, Phosphate 1.51 $1.73 \mathrm{mg} / \mathrm{l}$, Chloride 39.2 - $41.8 \mathrm{mg} / \mathrm{l}$, MPN 68-860.

Another lake is present in the university campus near the Music Department which provides water to the Distance Education staff and Girls hostel water requirements. The Storage capacity of that lake is 99.5 million cubic feet but storage by the average it never rises above 1.86 million cubic feet. The physical \& chemical changes in time variation of six months are as follows: Temperature $13.5-25^{\circ} \mathrm{C}, \mathrm{pH} 6.85-8.05$ more like alkaline water present in the lake. Turbidity $4.05-7.3 \mathrm{NTU}$, Hardness $58-263 \mathrm{mg} / \mathrm{l}$, Alkalinity $56-228 \mathrm{mg} / \mathrm{l}$, Acidity $15-23.5 \mathrm{mg} / \mathrm{l}$, D.O. $3.4-4.8$ $\mathrm{mg} / \mathrm{l}$, B.O.D. $6.5-33.78 \mathrm{mg} / \mathrm{l}$, C.O.D. $23.3-159$ $\mathrm{mg} / \mathrm{l}$, Phosphate $1.47-2.63 \mathrm{mg} / \mathrm{l}$, Nitrate $1.47-2.63$ $\mathrm{mg} / \mathrm{l}$, Chloride 16.3 - $45.16 \mathrm{mg} / \mathrm{l}$, MPN 55 - 1260.

Smita R. Jadhav et. al. (2017) in this paperwork they collected sample from four sites at Kotithirtha Lake. In order to achieve drinking water properties in the water sample, they came to conclusion its undesirable to drinking and also for other uses. Water contamination is far beyond filtration; contamination not just crosses permissible level but also gets highly polluted. By conducting various experiments on the samples they calculated the WQI of sample, and using water quality index as the rating scale for the physicchemical parameters of water sample.

\begin{tabular}{|l|l|}
\hline $\begin{array}{l}\text { Range of Rating } \\
\text { Scale (Vr) }\end{array}$ & Significance \\
\hline 100 & Clean \\
\hline $80-99.99$ & Slightly Polluted \\
\hline $60-79.99$ & Moderately Polluted \\
\hline $40-59.99$ & Excessively Polluted \\
\hline Excessively Polluted & Severely Polluted \\
\hline
\end{tabular}

Range of rating scale $(\mathrm{Vr})$ and significance for the physic-chemical parameters
As per the above table, station had 45.4 WQI so it is considered heavily polluted. So, the station 2 is 42.5 , Station 3 is 45.4 and station 4 is 42.5 had highly polluted WQI.

Abhijeet S. Ghone et. al. (2015) in this research paper deep study about rankala lake pollution and water quality studies conduct. By visually analysis of the lake it is clear that municipal waste is dumping into the lake at various points, so researcher chose the 5 points around the lake to collect the samples exact opposite points where waste water is dumping into lake by four various points such as Sham Society Nalla, Sairnaik Colony Nalla, Partala Nallla, Deshmukh Nalla. Many other activities such as bathing on lake, washing animals, vehicals and clothes, Ganesh idols and nirmalya immersion, dumping remaing foods from chawpati in lake is also contributing pollution in lake area. According to the readings Average $\mathrm{pH}$ of water is around 6 to 7.2 and having calcium hardness, because of the high chloride content it makes water rich inorganic constitutes which helps to promotes excessive plant growth and decay, favours certain weedy species. Still the pollution around lake is moderate, but water is unsuitable for human use.

K. B. Koli et. al. (2014) this paper conducted physicochemical analysis of Tulashi Tank dam water analysis. Tulashi tank is artificially earthen dam with masonry spillway. The purpose of the paper is to observed levels of studied parameters with the corresponding WHO and BIS guidelines values for drinking-water quality. The method to study of physicochemical parameters of water carried out during the period of January 2008 to December 2008, the sample was collected by 4 station respectively from human or animal interference from 1 to 1.5 meter depth, in 2-3 liter capacity containers. Temperature and $\mathrm{pH}$ check at the time of collection. According to physical parameters, water is transparent and varied from $32.45 \mathrm{~cm}$ to $44.56 \mathrm{~cm}$, so after laboratory testing Turbidity of water recorded within the range from 0.68 to 2.95 NTU in permissible limits. $\mathrm{pH}$ of water is averaging 7.5 , the temperature is $27^{\circ} \mathrm{C}$. D.O. of water is within $6.48-8.52 \mathrm{mg} / \mathrm{l}$, Alkalinity $126.42-162.42 \mathrm{mg} / \mathrm{l}$, Total hardness 82.48 - $156.26 \mathrm{mg} / \mathrm{l}$. After testing all results of various parameters of water it is concluded that water quality of Tulashi Tank meets the Permissible limits of water standards. It is cleared that certain water body is free 
from human activities and didn't get polluted by other reasons.

S.D.Jadhav et. al. (2011) this research paperwork carried out to evaluate borewell water quality of Ajara Tahsil for drinking and domestic purpose. Bore well sample collected from 51 villages of Ajara for physicochemical parameters testing in April month 2011.only certain parameters considered important like temperature, $\mathrm{pH}$, Electric conductivity, and hardness, chloride and Dissolved oxygen. Sample temperature within $19-21^{\circ} \mathrm{C}$ and $\mathrm{pH}$ ranged 6.5 to 8.4 all in permissible range. Electric conductivity varies between $0.12-1.22$ mmhos which indicates some ions present in water, Alkalinity 10 - $92 \mathrm{mg} / 1$, Hardness due to Calcium is $8.02-72.18 \mathrm{mg} / \mathrm{l}$ and due to Magnesium $6.16-86.42 \mathrm{mg} / \mathrm{l}$. The final conclusion of analysis based on the hardness of sample, 43 out of 51 bore well samples are within limits \& fit for drinking purpose.

A. A. Lole et. al. (2016) this research paper contained the parameters of Atigre village Bore well water and further studies, 25 samples of various bore well water sources collect in one- litre bottles to experimental studies. The Concentration of different chemical parameters of water samples of study area divided in two stages in pre-monsoon season and post-monsoon. The chemical quality of bore well and surface water samples of Atigre Village, reveals that $100 \%$ samples of pre and post-monsoon seasons represent $\mathrm{Ca}+\mathrm{Mg}>$ $\mathrm{Na}+\mathrm{K}$ (alkaline earths exceed alkalies) hydrochemical facies. Similarly, $100 \%$ water samples belong to $\mathrm{HCO} 3+\mathrm{CO} 3>\mathrm{Cl}+\mathrm{SO} 4$ (weak acid exceed strong acid) hydrochemical facies in pre and post-monsoon seasons. Classification of groundwater based on Piper Trilinear diagram indicates the Electrical conductivity activities related to quality of water, and it is clear or say fit to use for irrigation purpose.

Mangalekar. S. B. et. al. (2012) in this review paper conducts the study on groundwater analysis and availability to meet future requirements and studied on present condition also level of water table. To know the present status of groundwater in the study area, secondary data related to Kolhapur district such as population, number of industries, different uses of groundwater, groundwater level, groundwater quality was collected from various Government departments such as Maharashtra Pollution Control Board (MPCB), Groundwater Survey and Development Agency (GSDA), Central Groundwater Board,
Ministry of Water Resources Government of India, Kolhapur Collector office, Kolhapur Zilha Parishad, Kolhapur Municipal Corporation, and various research papers related to groundwater in Kolhapur district. By studying various research papers and review papers predicting future of groundwater conditions in Kolhapur.

\section{Conclusion:}

From the results of above review papers, it is concluded that most of the surface water polluted by human activities and groundwater storage is limited. Surface water quality is very poor that it is not potable and also domestic use purpose. Groundwater is in the permissible limit but quantity is very adequate. By analyzing various properties of water surface water contaminated by lead, excessive zinc, heavy metals, pesticides, plastics, cloths and other polluted constituents. Where groundwater quality maintains within the permissible limit throughout the Kolhapur district, it is fit for drinking and domestic purpose. This review paper help to analyse Kolhapur district water status both groundwater and surface water. It is also come in useful in the filtration methods for various water qualities.

\section{Reference:}

1) Smita R. Jadhav, Akshay R. Thorvat, Shrikant M. Bhosale " A Study On The Physico-Chemical Characteristics Of Kotitirth Lake Water In Kolhapur City, Ms, India" Department of Technology, Shivaji University, Kolhapur, Maharashtra International Journal of Research in Engineering and Technology Volume: 06 Issue: 10,2017

2) A. A. Lole, S. B. Kore, A. C. Varute, A. K. Chougule, A. R. Kutre, A. S. Ambi "Study Of Physicochemical Characteristics Of Groundwater Quality In Atigre Village, Kolhapur, Maharashtra, India" Department of Civil Engineering, Sanjay Ghodawat Institutes, Atigre Maharashtra International Research Journal of Engineering and Technology (IRJET) Volume: 03 Issue: 05 | May2016 pp 1767 - 1770

3) Abhijeet S. Ghone, Sunil K. Singal "Study On Pollution Sources, Waterquality And Conservation Of Rankala Lake, Kolhapur, India" Alternate Hydro Energy Centre, IIT Roorkee, Uttarakhand, (India) International Journal of Advanced 
Technology in Engineering and Science Volume No.03, Issue No. 01, January 2015 pp 565-574

4) K. B. Koli, and D. V. Muley "Water Quality Assessment of Tulashi Tank from Kolhapur District, Maharashtra, India" Department of Biology, The New College, Kolhapur, International Journal of Emerging Research in Management \&Technology ISSN: 2278-9359 (Volume-3, Issue-4) 2014

5) S.D.Jadhav, R.S. Sawant, A.G.Godghate, S.R. Patil and R.S. Patil "Assessment Of Ground Water Quality Of Ajara Tahsil From Maharashtra" Dr. Ghali College, Gadhinglaj-416502, Kolhapur Vol.
6) Mangalekar. S. B. and Samant J. S. Future Groundwater Disaster:A Case Study Of Kolhapur District Department of Environmental Science, Shivaji University, Kolhapur Proceeding of International Conference SWRDM-2012 pp 193202

7) Patil Shilpa G., Chonde Sonal Goroba, Jadhav Aasawari Suhas, Prakash D. Raut "Study of physicochemical and biological characteristics of lakes from Shivaji University Campus, Kolhapur, Maharashtra" Department of Environmental Science, Shivaji University, Kolhapur Adv. Appl. Sci. Res., 2011, 2(6): p.p. 505-519 5 | No.2 | April-June | 2012 ISSN: 0974-1496 | CODEN: RJCABP pp 246-249 